\title{
Widening social inequalities in mortality: the case of Barcelona, a southern European city
}

\author{
Carme Borrell, Antoni Plasència, Isabel Pasarin, Vicente Ortún
}

\begin{abstract}
Objective-To analyse trends in mortality inequalities in Barcelona between 1983 and 1994 by comparing rates in those electoral wards with a low socioeconomic level and rates in the remaining wards.

Design-Mortality trends study.

Setting-The city of Barcelona (Spain).

Subjects-The study included all deaths among residents of the two groups of city wards. Details were obtained from death certificates.

Main outcome measures-Age standardised mortality rates, age standardised rates of years of potential life lost, and age specific mortality rates in relation to cause of death, sex, and year were computed as well as the comparative mortality figure and the ratio of standardised rates of years of potential life lost.
\end{abstract}

Results-Rates of premature mortality increased from 5691.2 years of potential life lost per 100000 inhabitants aged 1 to 70 years in 1983 to 7606.2 in 1994 in the low socioeconomic level wards, and from 3731.2 to 4236.9 in the other wards, showing an increase in inequalities over the 12 years, mostly due to AIDS and drug overdose as causes of death. Conversely, cerebrovascular disease showed a reduction in inequality over the same period. Overall mortality in the 15-44 age group widened the gap between both groups of wards.

Conclusion-AIDS and drug overdose are emerging as the causes of death that are contributing to a substantial increase in social inequality in terms of premature mortality, an unreported observation in European urban areas.

Municipal Institute of Health and Catalonia School of Public

Health, Barcelona,

Spain

C Borrell

A Plasència

I Pasarin

Pompeu Fabra

University. Barcelona,

Spain

V Ortún

Correspondence to

Dr C Borrell, Municipal

Institute of Health, Pl.

Lesseps 1, 08023 Barcelona, Spain.

Accepted for publication January 1997

\section{(F Epidemiol Community Health 1997;51:659-667)}

There is currently no doubt that there are social inequalities in health, even in countries with high levels of social welfare..$^{1-5}$ Moreover, these inequalities have increased over the years, since health in general has improved much more for the wealthier classes..$^{6-10}$

Health inequalities in cities share characteristics distinctive of urban areas, with zones ranging from wealthy to marginal, and often also pockets of poverty. ${ }^{11-13}$ Inequalities in mortality have been shown in New York-where the Harlem district showed rates similar to those of Bangladesh. ${ }^{14}$ Other authors have related mortality to socioeconomic indicators, as shown in the city of Bristol, where the wards with the lowest socioeconomic levels were those with highest mortality. ${ }^{15}$

There have been few studies of health inequalities in southern European countries, ${ }^{16}{ }^{17}$ and even fewer studies looking at urban areas. In the city of Barcelona (Spain), several ecological studies of inequality in mortality have indicated important inequalities in the different geographical areas of the city: inequalities which are related to socioeconomic level. ${ }^{18-22}$ However, the evolution of these inequalities over time has never been studied.

The present study aimed to analyse trends in mortality inequalities in Barcelona. Mortality rates in electoral wards with low socioeconomic level were compared with the remainder over a period of 12 years from 1983-94.

\section{Methods}

AREAS STUDIED

This study was conducted in Barcelona, the second largest city in Spain (1 650000 inhabitants), located in the north east of the Iberian Peninsular. It is undergoing a process of transition from an industrial to a service city and its population is ageing.

This was a mortality trends study. All deaths (whether occurring in Barcelona or not) of residents of the city during the period 1983-94 were studied.

The city's 38 wards had been divided, in a prior analysis, into two groups: one comprised wards with a low socioeconomic level and the other included the remainder. The method employed was cluster analysis using socioeconomic variables (unemployment and illiteracy) obtained from local censuses corresponding to the years 1981, 1986, and 1991. Wards were divided in two groups only because of the small numbers of deaths in each ward and also because there is an important degree of homogeneity in the high socioeconomic level wards, both in terms of socioeconomic indicators and in terms of mortality. ${ }^{2123}$

There were 11 wards with a low socioeconomic level (and a population of some 300000 inhabitants) These were the older inner city wards as well as a few new peripheral wards. The other group comprised 27 wards with a total population of 1400000 inhabitants.

SOURCES OF DATA

Mortality data for residents in the years 1983-94 were obtained from death certificates. The home address for each resident who died was obtained from the municipal census, which is linked with the mortality register. A few deaths only were assigned to an institutional 
address, and most of these were located outside the deprived area.

Population denominators for each ward came from the local censuses of 1986 and 1991. For the years between 1986 and 1991 an estimate of the intercensal population was obtained based on a geometric curve. ${ }^{24}$ In the calculation of infant mortality rates, data on all births between 1983 and 1994 were used as denominators. For the calculation of age standardised rates, the reference population was that of Barcelona as a whole, according to the 1986 municipal census.

INDICATORS AND STATISTICAL ANALYSES

The underlying cause of death was coded using the International Classification of Diseases, 9th revision (ICD-9) ${ }^{25}$ The causes of death studied were: tuberculosis (10-18), AIDS (279.5), all infectious diseases including AIDS (1-139, 279.5), malignant tumour of the lung (162), malignant tumour of the breast (174), all tumours (140-239), ischaemic heart disease (410-414), cerebrovascular diseases (430438), all diseases of the circulatory system (390-459), all diseases of the respiratory apparatus (460-519), cirrhosis (571), all diseases of the digestive system (520-579), drug overdose
KEY POINTS

- The increase in social inequality in terms of premature mortality seen in Barcelona between 1983 and 1994 is primarily due to two main causes of death - AIDS and drug overdose.

- This has led to increased inequality in specific mortality rates for the age group 15-44 years.

- The third cause of death which has accounted for the increase in inequality is lung cancer in men.

- In public health terms, this study emphasises the need to implement more equitable health policies.

and poisonings (E850-E858), and all external causes (E800-E999).

We computed age standardised mortality rates (direct method) ${ }^{26}$ by sex and year in each group of wards, as well as the age standardised rate of years of potential life lost (YPLL). The standard population was the total Barcelona population by sex. Deaths in subjects aged between 1 and 70 years were included in the calculation of YPLL. We limited the age studied to 70 , as proposed by Romeder and

Table 1 Standardised mortality rates for the years 1983 and 1994 and slopes of regression lines in the two groups of wards in relation to cause of death and sex. Barcelona, 1983-94

\begin{tabular}{|c|c|c|c|c|c|c|c|}
\hline \multirow[b]{2}{*}{ Cause of death } & \multirow[b]{2}{*}{$\operatorname{Sex}$} & \multicolumn{3}{|c|}{ Wards of low socioeconomic level } & \multicolumn{3}{|l|}{ Rest of wards } \\
\hline & & $1983 M R(n o)$ & $1994 M R(n o)$ & $B$ & $1983 M R$ (no) & $1994 M R(n o)$ & $B$ \\
\hline \multirow[t]{3}{*}{ Tuberculosis } & $\mathbf{M}$ & $7.3(11)$ & $4.3(6)$ & 0.07 & $2.4(16)$ & $1.7(12)$ & -0.09 \\
\hline & $\mathrm{F}$ & $0.0(-)$ & $0.6(1)$ & -0.01 & $0.9(7)$ & $1.9(16)$ & -0.00 \\
\hline & $\mathrm{T}$ & $3.6(11)$ & $2.4(7)$ & 0.03 & $1.6(23)$ & $1.8(28)$ & -0.04 \\
\hline \multirow[t]{3}{*}{ AIDS } & $\dot{M}$ & $0.0(-)$ & $73.6(104)$ & $6.80^{\star}$ & $0.0(-)$ & $29.2(196)$ & $3.10^{\star}$ \\
\hline & $\mathrm{F}$ & $0.0(-)$ & $22.7(33)$ & $1.98^{\star}$ & $0.0(-)$ & $6.4(48)$ & $0.59^{\star}$ \\
\hline & $\mathrm{T}$ & $0.0(-)$ & $48.0(137)$ & $4.38^{\star}$ & $0.0(-)$ & $17.1(244)$ & $1.77^{\star}$ \\
\hline \multirow[t]{3}{*}{ Total infectious diseases (including AIDS) } & $M$ & $10.9(16)$ & $87.1(124)$ & $7.33^{\star}$ & $5.7(38)$ & $36.3(247)$ & $3.21^{\star}$ \\
\hline & $\mathrm{F}$ & $6.2(9)$ & $30.1(45)$ & $2.26^{\star}$ & $3.5(26)$ & $12.5(102)$ & $0.78^{\star}$ \\
\hline & $\mathrm{T}$ & $8.5(25)$ & $58.4(169)$ & $4.78^{\star}$ & $4.5(64)$ & $23.7(349)$ & $1.92^{\star}$ \\
\hline \multirow[t]{3}{*}{ Lung cancer } & $\mathbf{M}$ & $86.5(125)$ & $119.8(181)$ & $2.84^{\star}$ & $70.4(467)$ & 83.4 (597) & $1.00^{\star}$ \\
\hline & $\mathrm{F}$ & $7.1(11)$ & $8.5(14)$ & -0.00 & $10.1(75)$ & $11.5(93)$ & -0.01 \\
\hline & $\mathrm{T}$ & $44.9(136)$ & $62.4(195)$ & $1.47^{\star}$ & $38.7(542)$ & $46.0(690)$ & $0.52^{\star}$ \\
\hline Breast cancer & $\mathrm{F}$ & $35.0(55)$ & $35.1(55)$ & 0.82 & $33.2(245)$ & $38.0(300)$ & $0.55^{\star}$ \\
\hline \multirow[t]{3}{*}{ Total cancers } & $\mathrm{M}$ & $341.7(482)$ & $358.0(535)$ & $3.99^{\star}$ & $267.4(1779)$ & $304.0(2222)$ & $3.01^{\star}$ \\
\hline & $\mathrm{F}$ & $181.9(280)$ & $206.5(330)$ & $1.76^{\star}$ & $181.7(1347)$ & $190.2(1566)$ & 0.51 \\
\hline & $\mathrm{T}$ & $257.1(762)$ & $279.8(865)$ & $3.06^{\star}$ & $22.4(3126)$ & $245.1(3788)$ & $1.80^{\star}$ \\
\hline \multirow{3}{*}{ Ischaemic heart disease } & $M$ & $118.5(166)$ & $126.5(184)$ & 0.95 & $103.6(693)$ & $106.2(800)$ & 0.17 \\
\hline & $\mathrm{F}$ & $96.6(140)$ & $80.0(130)$ & -0.82 & $80.7(606)$ & $73.7(667)$ & -0.18 \\
\hline & $\mathrm{T}$ & $107.1(306)$ & $101.9(314)$ & 0.06 & $91.5(1299)$ & $89.5(1467)$ & 0.03 \\
\hline \multirow[t]{3}{*}{ Cerebrovascular disease } & $\mathbf{M}$ & $134.0(176)$ & $80.3(114)$ & $-4.30^{\star}$ & $100.4(679)$ & $70.9(554)$ & $-2.63^{\star}$ \\
\hline & $\mathrm{F}$ & $150.0(217)$ & $122.6(199)$ & $-3.97^{\star}$ & $146.8(1106)$ & $98.0(901)$ & $-4.81^{\star}$ \\
\hline & $\mathrm{T}$ & $141.8(393)$ & $102.5(313)$ & $-4.05^{\star}$ & $124.8(1785)$ & $85.3(1455)$ & $-3.76^{\star}$ \\
\hline \multirow[t]{3}{*}{ Total cardiac diseases } & $\mathrm{M}$ & $434.9(583)$ & $314.4(452)$ & $-8.97^{\star}$ & $350.6(2365)$ & $275.8(2126)$ & $-6.75^{\star}$ \\
\hline & $\mathrm{F}$ & $504.9(721)$ & $361.9(588)$ & $-12.19^{\star}$ & $419.3(3161)$ & 309.8 (2857) & $-9.89^{\star}$ \\
\hline & $\mathrm{T}$ & $471.3(1304)$ & $340.1(1040)$ & $-10.46^{\star}$ & $386.7(5526)$ & $294.3(4983)$ & $-8.33^{\star}$ \\
\hline \multirow{3}{*}{ Total respiratory diseases } & $\mathbf{M}$ & $101.6(136)$ & $121.3(170)$ & 1.15 & $68.5(462)$ & $78.8(620)$ & 1.25 \\
\hline & $\mathrm{F}$ & $65.9(94)$ & $49.0(80)$ & -0.67 & $55.7(419)$ & $49.2(454)$ & -0.18 \\
\hline & $\mathrm{T}$ & $82.5(230)$ & $81.7(250)$ & 0.15 & $61.8(881)$ & $63.4(1074)$ & 0.52 \\
\hline \multirow{3}{*}{ Cirrhosis } & $\mathbf{M}$ & $60.2(90)$ & $52.0(76)$ & $-0.98^{\star}$ & $38.4(254)$ & $24.5(171)$ & $-1.31^{\star}$ \\
\hline & $\mathrm{F}$ & $32.3(50)$ & $28.5(46)$ & -0.63 & $17.9(132)$ & $19.5(157)$ & -0.23 \\
\hline & $\mathrm{T}$ & $45.7(140)$ & $40.2(122)$ & $-0.77^{\star}$ & $27.6(386)$ & $21.9(328)$ & -0.74 \\
\hline \multirow[t]{3}{*}{ Total digestive diseases } & $\mathrm{M}$ & $105.4(152)$ & $84.1(122)$ & $-2.28^{\star}$ & $65.3(434)$ & $45.1(331)$ & $-1.79^{\star}$ \\
\hline & $\mathrm{F}$ & $68.5(104)$ & $61.6(100)$ & $-1.38^{\star}$ & $40.7(303)$ & $42.1(357)$ & -0.55 \\
\hline & $\mathrm{T}$ & $86.3(256)$ & $73.0(222)$ & $-1.78^{\star}$ & $52.3(737)$ & $43.5(688)$ & $-1.13^{\star}$ \\
\hline \multirow{3}{*}{ Drug overdose } & $\mathbf{M}$ & $0.0(-)$ & $21.7(31)$ & $2.47^{\star}$ & $0.0(-)$ & $7.1(47)$ & $0.90^{\star}$ \\
\hline & $\mathrm{F}$ & $0.0(-)$ & $5.0(7)$ & $0.55^{\star}$ & $0.0(-)$ & $1.9(15)$ & $0.19^{\star}$ \\
\hline & $\mathrm{T}$ & $0.0(-)$ & $13.3(38)$ & $1.50^{\star}$ & $0.0(-)$ & $4.3(62)$ & $0.52^{\star}$ \\
\hline \multirow[t]{3}{*}{ Total external causes } & $M$ & $50.7(72)$ & $66.0(93)$ & $3.09^{\star}$ & $36.7(244)$ & $46.1(315)$ & $1.38^{\star}$ \\
\hline & $\mathrm{F}$ & $38.8(58)$ & $36.1(55)$ & -0.30 & $25.1(187)$ & $24.4(204)$ & 0.07 \\
\hline & $\mathrm{T}$ & 44.8 (130) & $50.3(148)$ & 1.34 & $30.6(431)$ & $34.7(519)$ & 0.70 \\
\hline \multirow[t]{3}{*}{ Total causes } & $M$ & 1145.0 (1577) & $1141.9(1651)$ & 5.21 & $868.2(5819)$ & $876.6(6546)$ & 0.58 \\
\hline & $\mathrm{F}$ & $978.2(1433)$ & $890.1(1430)$ & -9.29 & $811.1(6081)$ & $746.2(6598)$ & -6.59 \\
\hline & $\mathrm{T}$ & $1056.4(3010)$ & $1012.1(3081)$ & -1.83 & $838.2(11900)$ & $809.8(13144)$ & -2.97 \\
\hline
\end{tabular}

M: males, F: females, T: males and females, B: slope of regression line, MR: standardised mortality rate per 100000 inhabitants, n: number of deaths. $\star \mathrm{p}<0.05$. 
Table 2 Comparative mortality figures and ratio of standardised rates of potential years of life lost between the wards of low socioeconomic level and the rest of wards by cause of death and sex. Barcelona, 1983-94

\begin{tabular}{|c|c|c|c|c|c|}
\hline \multirow[b]{2}{*}{ Cause of death } & \multirow[b]{2}{*}{ Sex } & \multicolumn{2}{|c|}{ Comparative mortality figure } & \multicolumn{2}{|l|}{$R Y P L L$} \\
\hline & & 1983 & 1994 & 1983 & 1994 \\
\hline \multirow{3}{*}{ Tuberculosis } & $M$ & $303.7^{\star}$ & 255.0 & $666.0^{\star}$ & $410.0^{\star}$ \\
\hline & $\mathrm{F}$ & - & 33.3 & - & - \\
\hline & $\mathrm{T}$ & $217.7^{\star}$ & 136.0 & $519.4^{\star}$ & $398.1^{\star}$ \\
\hline \multirow[t]{3}{*}{ AIDS } & M & - & $251.7^{\star}$ & - & $267.4^{\star}$ \\
\hline & $\mathrm{F}$ & - & $356.3^{\star}$ & - & $368.0^{\star}$ \\
\hline & $\mathrm{T}$ & - & $280.4^{\star}$ & - & $297.0^{\star}$ \\
\hline \multirow{3}{*}{ Total infectious diseases (including AIDS) } & $M$ & $191.4^{\star}$ & $240.1^{\star}$ & $293.4^{\star}$ & $277.6^{\star}$ \\
\hline & $\mathrm{F}$ & $177.1^{\star}$ & $241.1^{\star}$ & 5.5 & $380.4^{\star}$ \\
\hline & $\mathrm{T}$ & $187.9^{\star}$ & $246.4^{\star}$ & 199.3 & $307.5^{\star}$ \\
\hline \multirow[t]{3}{*}{ Lung cancer } & $\mathbf{M}$ & $122.8^{\star}$ & $143.7^{\star}$ & 118.8 & $151.8^{\star}$ \\
\hline & $\mathbf{F}$ & 70.4 & 74.4 & 136.9 & 55.9 \\
\hline & $\mathrm{T}$ & 116.0 & $135.8^{\star}$ & 124.2 & $144.7^{\star}$ \\
\hline Breast cancer & $\mathbf{F}$ & 105.6 & 92.4 & 119.1 & 112.7 \\
\hline \multirow[t]{3}{*}{ Total cancers } & $M$ & $122.8^{\star}$ & $117.8^{\star}$ & $123.2^{\star}$ & $139.7^{\star}$ \\
\hline & $\mathbf{F}$ & 100.1 & 108.6 & 121.1 & $143.8^{\star}$ \\
\hline & $\mathrm{T}$ & $115.6^{\star}$ & $114.2^{\star}$ & $123.3^{\star}$ & $142.9^{\star}$ \\
\hline \multirow[t]{3}{*}{ Ischaemic heart disease } & $\mathbf{M}$ & 114.3 & $119.1^{\star}$ & $142.3^{\star}$ & 93.7 \\
\hline & $\mathbf{F}$ & 119.7 & 108.5 & 104.0 & 155.0 \\
\hline & $\mathrm{T}$ & $117.0^{\star}$ & $113.8^{\star}$ & $139.6^{\star}$ & 106.3 \\
\hline \multirow[t]{3}{*}{ Cerebrovascular disease } & $\mathbf{M}$ & $133.5^{\star}$ & 113.2 & 138.1 & 150.6 \\
\hline & $\mathbf{F}$ & 102.2 & $125.1^{\star}$ & $366.2^{\star}$ & 168.1 \\
\hline & $\mathrm{T}$ & $113.7^{\star}$ & $120.2^{\star}$ & $203.6^{\star}$ & $158.6^{\star}$ \\
\hline \multirow{3}{*}{ Total cardiac diseases } & $\mathbf{M}$ & $124.0^{\star}$ & $114.0^{\star}$ & $148.5^{\star}$ & $142.9^{\star}$ \\
\hline & $\mathrm{F}$ & $120.4^{\star}$ & $116.8^{\star}$ & $195.9^{\star}$ & $166.6^{\star}$ \\
\hline & $\mathrm{T}$ & $121.9^{\star}$ & $115.6^{\star}$ & $163.6^{\star}$ & $151.7^{\star}$ \\
\hline \multirow[t]{3}{*}{ Total respiratory diseases } & $\mathbf{M}$ & $148.3^{\star}$ & $154.0^{\star}$ & $191.0^{\star}$ & $179.4^{\star}$ \\
\hline & $\mathrm{F}$ & 118.4 & 99.7 & 129.0 & 82.8 \\
\hline & $\mathrm{T}$ & $133.5^{\star}$ & $128.8^{\star}$ & $171.8^{\star}$ & 153.9 \\
\hline \multirow[t]{3}{*}{ Cirrhosis } & $\mathbf{M}$ & $156.5^{\star}$ & $212.6^{\star}$ & $142.9^{\star}$ & $298.4^{\star}$ \\
\hline & $\mathrm{F}$ & $180.7^{\star}$ & $145.6^{\star}$ & $196.9^{\star}$ & 134.9 \\
\hline & $\mathrm{T}$ & $165.7^{\star}$ & $183.8^{\star}$ & $159.4^{\star}$ & $251.0^{\star}$ \\
\hline \multirow{3}{*}{ Total digestive diseases } & $\mathbf{M}$ & $161.6^{\star}$ & $186.5^{\star}$ & $171.0^{\star}$ & $256.7^{\star}$ \\
\hline & $\mathrm{F}$ & $168.5^{\star}$ & $146.4^{\star}$ & $184.4^{\star}$ & 122.6 \\
\hline & $T$ & $165.0^{\star}$ & $167.7^{\star}$ & $177.5^{\star}$ & $219.4^{\star}$ \\
\hline \multirow[t]{3}{*}{ Drug overdose } & $\mathbf{M}$ & - & $307.1^{\star}$ & - & $291.4^{\star}$ \\
\hline & $\mathrm{F}$ & - & $264.7^{\star}$ & - & 250.6 \\
\hline & $\mathrm{T}$ & - & $306.9^{\star}$ & - & $292.5^{\star}$ \\
\hline \multirow{3}{*}{ Total external causes } & $\mathbf{M}$ & $138.0^{\star}$ & $143.2^{\star}$ & $183.2^{\star}$ & $158.4^{\star}$ \\
\hline & $\mathrm{F}$ & $155.0^{\star}$ & $147.9^{\star}$ & $197.6^{\star}$ & 171.9 \\
\hline & $\mathrm{T}$ & $146.5^{\star}$ & $145.0^{\star}$ & $190.4^{\star}$ & $164.5^{\star}$ \\
\hline \multirow{3}{*}{ Total causes } & $\mathbf{M}$ & $131.9^{\star}$ & $130.3^{\star}$ & $154.5^{\star}$ & $176.0^{\star}$ \\
\hline & $\mathbf{F}$ & $120.6^{\star}$ & $119.3^{\star}$ & $143.0^{\star}$ & $176.7^{\star}$ \\
\hline & $\mathrm{T}$ & $126.0^{\star}$ & $125.0^{\star}$ & $152.5^{\star}$ & $179.5^{\star}$ \\
\hline
\end{tabular}

M: males, F: females, T: total, RYPLL: ratio of standardised rates of potential years of life lost.

$\star 95 \%$ confidence interval does not include the value of 100 .

McWhinnie. ${ }^{27}$ Finally, age specific mortality rates were also calculated.

The ratio of standardised mortality rates for the two groups of wards (comparative mortality figures, CMF) and the ratio of standardised rates of YPLL in the two groups of wards (RYPLL) were calculated for each year, along with their corresponding $95 \%$ confidence intervals $(95 \% \mathrm{CI}) .^{26}$

To describe the evolution of mortality in each group of wards, a linear regression model was fitted to the annual rates over the 12 year study period. The slope (B) of the regression line is interpreted as the mean value by which the rate increases or decreases each year. To test the compliance of the model assumptions, residual analysis was carried out. Graphs were drawn of the normal probability of the standardised values (P-P plot) and also of the standardised residuals as a function of the standardised predicted values. ${ }^{28}$ No important violations were identified. In all analyses a difference was considered to be statistically significant when the $p$ value was less than 0.05 .

\section{Results}

GENERAL MORTALITY

During the 12 years studied, overall mortality rates were consistently higher in the wards with low socioeconomic level and this difference remained stable over time. Mortality for all causes fell from 1056.4 deaths per 100000 inhabitants in 1983 to 1012.1 in 1994 in the low socioeconomic level wards, and from 838.2 to 809.8 in the remaining wards (table 1).

Nevertheless, for some causes inequalities increased. This was the case for AIDS mortality, which increased more in the low socioeconomic level wards than in the others. AIDS, which was a non-existent cause of mortality in 1983 (the first case appeared in 1986), accounted for $4.4 \%$ of deaths in the low socioeconomic level wards and $1.9 \%$ of deaths in the remaining wards in 1994. The CMF in 1994 was 280.4 (95\% CI: 227, 346) (table 2).

Another cause of death for which inequalities increased was drug overdose. Deaths from overdose were non-existent in 1983 (the first case appeared in 1984) but represented $1.2 \%$ of deaths in the low socioeconomic level wards and $0.5 \%$ of deaths in the other wards 12 years later. The CMF for 1994 was 306.9 (95\%CI: 205,460 ) (table 2). These increases had an important effect on the total deaths in the two large groups of causes-infectious diseases (slope was 4.38 for wards with low socioeconomic level and 1.77 for the rest of wards) and external causes (the two slopes were 1.34 and 0.70 ) - 


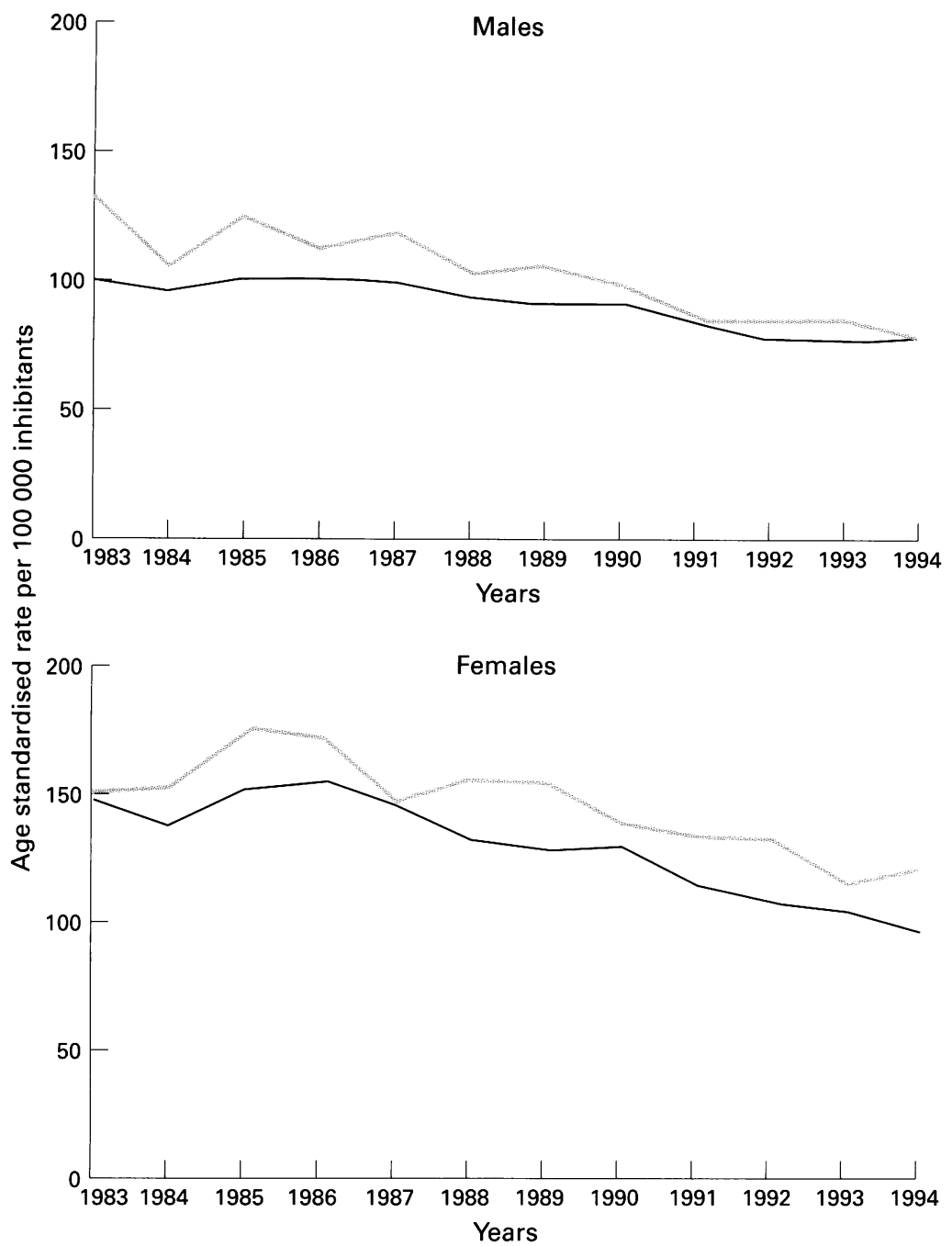

Figure 1 Evolution of mortality due to cerebrovascular disease in the low socioeconomic level wards (grey, upper lines) and other wards (lower lines). Males and females, Barcelona, 1983-94.

and occurred in both sexes, although the rates were higher among men (table 1).

Cancer of the lung among men also increased differentially, from 86.5 deaths per 100000 inhabitants in 1983 to 119.8 in 1994 in the low socioeconomic level wards, and from 70.4 to 83.4 in the others (table 1 ).

The only cause of death which showed a decrease in inequality during these years was cerebrovascular disease, particularly in men, since the rates fell more in the low socioeconomic level wards (table 1 and fig 1 ). In men, the CMF changed from 133.5 (95\%CI:113, 158 ) in 1983 to 113.2 (95\% CI: 92,139 ) in 1994 (table 2).

Inequalities between the two groups of wards remained stable for the other causes of death (table 1).

\section{PREMATURE MORTALITY}

With respect to premature mortality, it is noteworthy that the rates increased from 5691.2 YPLL per 100000 inhabitants aged 1 to 70 years in 1983 to 7606.2 in 1994 in the low socioeconomic level wards, and from 3731.2 to 4236.9 in the other wards. Such a differential increase in the rates in the two groups of wards has lead to an increase in inequalities over the 12 year period (table 3 ).
In relation to causes of premature death, AIDS and drug overdose are again the causes that show increases in inequalities. AIDS progressed from being a non-existent cause in 1983 to one with rates of 1823.9 YPLL per 100 000 inhabitants aged 1 to 70 years in 1994 in the low socioeconomic level wards, and of 614.0 in the other wards (fig 2). The RYPLL changed from 133.7 (95\% CI: 34, 523) in 1986 to 297.0 (95\% CI: 239,369$)$ in 1994 (table 2). This cause of death accounted for $24.0 \%$ of all YPLL in 1994 in the low socioeconomic level wards but for $14.5 \%$ in the others. Premature mortality from drug overdose also increased more in the low socioeconomic level wards (fig 2). In 1994 this cause accounted for $7.1 \%$ of the YPLL in low socioeconomic level wards and $4.3 \%$ in the others. As expected, these increases had an important effect on the total deaths in the two large groups of causes, infectious diseases and external causes (the slope was 67.3 for wards with a low socioeconomic level and 35.3 for the rest of wards). These increases occurred in both sexes, although the rates were higher among men (tables 2 and 3 ).

Lung cancer among men also increased differentially in the two groups of wards. Cirrhosis in men increased in the wards with low socioeconomic level but decreased in the rest of wards, widening the gap between them (tables 2 and 3 ).

Cerebrovascular disease in men and women, and ischaemic heart disease in men were the causes of death for which inequalities in premature mortality decreased and for which a larger decrease was seen in the low socioeconomic level wards (table 3 ). The RYPLL due to cerebrovascular disease changed from 203.6 (95\%CI: 145,286$)$ in 1983 to 158.6 (95\%CI: 102,246 ) in 1994 (table 2). This cause of death represented $7 \%$ of the YPLL in 1983 in the low socioeconomic level wards and $3.2 \%$ in 1994 . In the other wards the percentages changed from $5.3 \%$ to $2.9 \%$

Inequalities between the two groups of wards in terms of premature mortality due to other causes remained stable (table 3 ).

AGE SPECIFIC MORTALITY

When age specific mortality rates were considered, it appeared that inequalities increased considerably in both sexes in the age groups between 15 and 44 years, and above all in the low socioeconomic level wards. The rates for the age group from 25-34 increased from 114.9 per 100000 inhabitants in 1983 to 358.6 in 1994 in the low socioeconomic level wards and from 66.6 to 134.1 in the remaining wards. Increases in 35-44 years rates were from 194.9 to 327.6 in the low socioeconomic level wards and from 117.6 to 177.6 in the other ones (fig 3 and table 4)

The only age groups in which the rates and inequalities tended to decrease more in the low socioeconomic level wards were infants and children aged 1-14 years (table 4).

\section{Discussion}

The results show that the increase in social inequality associated with premature mortality 
Table 3 Standardised rates of potential years of life lost for the years 1983 and 1994 and slopes of regression lines in the two groups of wards by cause of death and sex. Barcelona, 1983-94

\begin{tabular}{|c|c|c|c|c|c|c|c|}
\hline \multirow[b]{2}{*}{ Cause of death } & \multirow[b]{2}{*}{ Sex } & \multicolumn{3}{|c|}{ Wards of low socioeconomic level } & \multicolumn{3}{|c|}{ Rest of wards } \\
\hline & & $1983 M Y$ & $1994 M Y$ & $B$ & $1983 \mathrm{MY}$ & $1994 M Y$ & $B$ \\
\hline \multirow{3}{*}{ Tuberculosis } & M & 128.9 & 74.4 & 4.61 & 19.3 & 18.1 & -0.19 \\
\hline & $\mathrm{F}$ & 0.0 & 0.0 & 1.49 & 6.2 & 1.5 & -0.15 \\
\hline & $\mathrm{T}$ & 65.3 & 38.0 & 3.12 & 12.6 & 9.5 & -0.17 \\
\hline \multirow{3}{*}{ AIDS } & $M$ & 0.0 & 2666.9 & $251.75^{\star}$ & 0.0 & 997.2 & $104.03^{\star}$ \\
\hline & $\mathrm{F}$ & 0.0 & 939.1 & $84.33^{\star}$ & 0.0 & 255.2 & $23.50^{\star}$ \\
\hline & $\mathrm{T}$ & 0.0 & 1823.9 & $170.12^{\star}$ & 0.0 & 614.0 & $62.47^{\star}$ \\
\hline \multirow[t]{3}{*}{ Total infectious diseases (including AIDS) } & M & 186.6 & 2908.0 & $264.55^{\star}$ & 63.6 & 1047.6 & $103.30^{\star}$ \\
\hline & $\mathrm{F}$ & 1.8 & 1001.8 & $86.39^{\star}$ & 32.5 & 263.4 & $23.00^{\star}$ \\
\hline & $\mathrm{T}$ & 94.8 & 1976.3 & $177.71^{\star}$ & 47.5 & 642.7 & $61.86^{\star}$ \\
\hline \multirow[t]{3}{*}{ Lung cancer } & $M$ & 558.3 & 812.8 & $27.29^{\star}$ & 470.0 & 535.5 & $9.27^{\star}$ \\
\hline & $\mathrm{F}$ & 91.3 & 42.0 & -2.63 & 66.7 & 75.2 & 1.02 \\
\hline & $\mathrm{T}$ & 325.4 & 434.1 & $12.96^{\star}$ & 262.0 & 300.0 & $5.24^{\star}$ \\
\hline Breast cancer & $\mathrm{F}$ & 444.8 & 396.4 & 6.39 & 373.6 & 351.8 & 2.79 \\
\hline \multirow[t]{3}{*}{ Total cancers } & M & 2216.3 & 2487.3 & 28.27 & 1798.4 & 1780.7 & 10.57 \\
\hline & $\mathrm{F}$ & 1471.7 & 1476.4 & 5.62 & 1215.0 & 1026.4 & -12.12 \\
\hline & $\mathrm{T}$ & 1846.2 & 1993.5 & 17.92 & 1497.6 & 1395.3 & -0.71 \\
\hline \multirow[t]{3}{*}{ Ischaemic heart disease } & $\mathrm{M}$ & 755.4 & 396.8 & -13.13 & 530.8 & 423.4 & -7.76 \\
\hline & $\mathrm{F}$ & 105.4 & 132.0 & 1.63 & 101.4 & 85.2 & -0.99 \\
\hline & $\mathrm{T}$ & 431.8 & 266.1 & -5.51 & 309.3 & 250.3 & $-4.11^{\star}$ \\
\hline \multirow{3}{*}{ Cerebrovascular disease } & M & 401.4 & 240.7 & $-10.06^{\star}$ & 290.6 & 159.8 & $-7.23^{\star}$ \\
\hline & $\mathrm{F}$ & 393.2 & 147.9 & -9.97 & 107.4 & 88.0 & $-4.05^{\star}$ \\
\hline & $\mathrm{T}$ & 399.3 & 195.1 & $-10.04^{\star}$ & 196.1 & 123.0 & $-5.54^{\star}$ \\
\hline \multirow[t]{3}{*}{ Total cardiac diseases } & $M$ & 1837.2 & 1320.7 & -27.26 & 1237.0 & 924.2 & $-22.85^{\star}$ \\
\hline & $\mathrm{F}$ & 795.2 & 572.8 & -14.35 & 405.9 & 343.8 & $-10.62^{\star}$ \\
\hline & $\mathrm{T}$ & 1322.3 & 951.2 & $-20.50^{\star}$ & 808.3 & 627.1 & $-16.25^{\star}$ \\
\hline \multirow[t]{3}{*}{ Total respiratory diseases } & $\mathrm{M}$ & 406.7 & 350.2 & -0.42 & 212.9 & 195.2 & -0.73 \\
\hline & $\mathrm{F}$ & 143.7 & 71.3 & 0.88 & 111.3 & 86.1 & -2.59 \\
\hline & $\mathrm{T}$ & 275.5 & 214.0 & 0.47 & 160.4 & 139.1 & -1.64 \\
\hline \multirow[t]{3}{*}{ Cirrhosis } & $M$ & 583.3 & 795.2 & 5.44 & 408.1 & 266.5 & $-12.78^{\star}$ \\
\hline & $\mathrm{F}$ & 277.8 & 173.6 & -5.50 & 141.0 & 128.7 & -3.67 \\
\hline & $\mathrm{T}$ & 430.9 & 490.9 & 0.40 & 270.2 & 195.6 & $-8.04^{\star}$ \\
\hline \multirow[t]{3}{*}{ Total digestive diseases } & $M$ & 921.4 & 986.9 & -0.37 & 538.7 & 384.4 & $-12.87^{\star}$ \\
\hline & $\mathrm{F}$ & 366.8 & 219.1 & -9.23 & 198.9 & 178.7 & -3.16 \\
\hline & $\mathrm{T}$ & 645.2 & 611.4 & -4.27 & 363.4 & 278.6 & -7.80 \\
\hline \multirow[t]{3}{*}{ Drug overdose } & $\mathrm{M}$ & 0.0 & 900.1 & $106.99^{\star}$ & 0.0 & 308.0 & $41.03^{\star}$ \\
\hline & $\mathrm{F}$ & 0.0 & 166.0 & $24.16^{\star}$ & 0.0 & 66.2 & $7.71^{\star}$ \\
\hline & $\mathrm{T}$ & 0.0 & 538.5 & $66.11^{\star}$ & 0.0 & 184.1 & $23.92^{\star}$ \\
\hline \multirow[t]{3}{*}{ Total external causes } & $\mathrm{M}$ & 1465.6 & 2006.2 & $121.88^{\star}$ & 800.0 & 1266.3 & $63.21^{\star}$ \\
\hline & $\mathrm{F}$ & 479.3 & 605.5 & 11.72 & 242.5 & 352.3 & 8.65 \\
\hline & $\mathrm{T}$ & 976.4 & 1310.1 & $67.26^{\star}$ & 512.7 & 796.2 & $32.29^{\star}$ \\
\hline \multirow{3}{*}{ Total causes } & $\mathrm{M}$ & 7671.8 & 10693.6 & $377.41^{\star}$ & 4966.8 & 6076.7 & $139.82^{\star}$ \\
\hline & $\mathrm{F}$ & 3678.2 & 4409.2 & $72.36^{\star}$ & 2571.5 & 2495.0 & 0.59 \\
\hline & $\mathrm{T}$ & 5691.2 & 7606.2 & $229.60^{\star}$ & 3731.2 & 4236.9 & $69.05^{\star}$ \\
\hline
\end{tabular}

M: males, F: females, T: males and females, B: slope of regression line, MY: standardised rate of potential years of life lost per 100000 inhabitants $1-70$ years.

in a southern European city was primarily due to two main causes of death-AIDS and drug overdose. This led to increased inequalities in specific mortality rates for the age groups 15-44 years. The third cause of death which accounted for the increase in inequalities was lung cancer among men.

Although there was a reduction in inequality between the low socioeconomic level wards and the others for cerebrovascular disease, the increased inequality in terms of premature mortality caused by AIDS and drug overdose negated its effect.

THE EVOLUTION OF INEQUALITIES IN TOTAL MORTALITY

Most of the published studies which have analysed the evolution of mortality inequalities have found that inequalities increased between socioeconomic groups. The majority of studies have been carried out in populations with an age limit (normally 65 years), something which would make their results more comparable with those obtained in Barcelona for premature mortality.

Studies on the evolution of mortality inequalities performed in the United Kingdom have described how the inequalities increased beyond 60 years of age. ${ }^{34-8}$ Regidor et al have reported an increase in inequality in mortality among men aged 20-64 years in eight Spanish provinces. ${ }^{17}$

One study of trends in a city was that undertaken in Glasgow. McCarron et al analysed the evolution of mortality inequalities in that city in those aged 15 to 64 years and compared wards of higher and lower socioeconomic levels. Mortality fell more in the wealthier areas, thereby causing inequalities to increase. In lower socioeconomic level wards, mortality increased among men aged $15-44$ years. ${ }^{29}$

Studies performed in the USA have also described an increase in mortality inequalities among people with different levels of education. ${ }^{93}$ On the other hand, one study carried out in The Netherlands, in which regions with higher and lower socioeconomic levels were compared over the period 1950-80 found no changes. ${ }^{10}$

THE EVOLUTION OF INEQUALITIES BY CAUSE OF DEATH AND AGE GROUPS

There are few studies which have analysed the evolution of different causes of death, particularly causes which have arisen recently, such as AIDS and drug overdose.

The important growth of AIDS as a cause of premature mortality has already been 


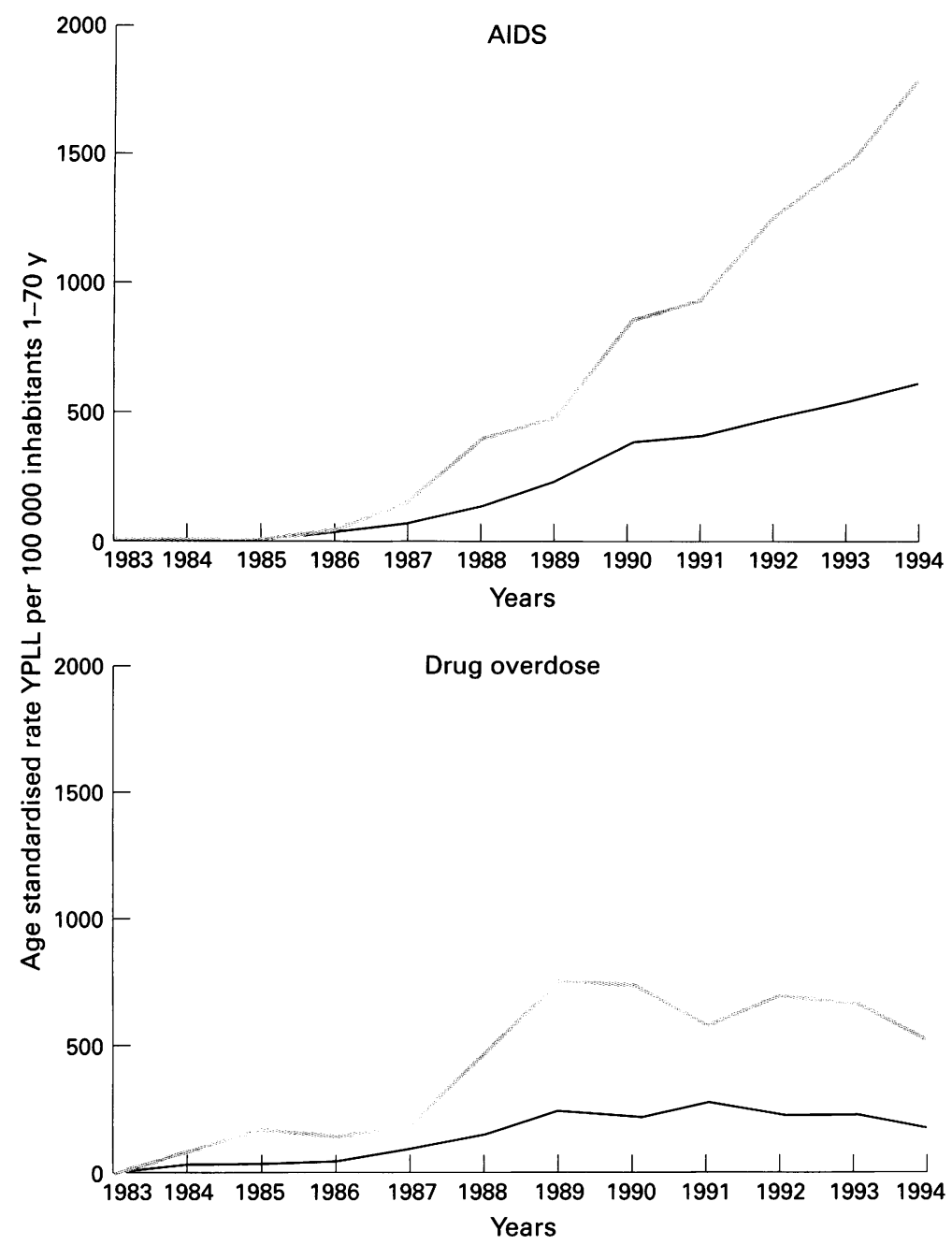

Figure 2 Evolution of premature mortality due to AIDS and drug overdose in the low socioeconomic level wards (grey, upper lines) and other wards (lower lines). Both sexes, Barcelona, 1983-94. described in Spain ${ }^{31}$ and in Catalonia. ${ }^{32}$ In Barcelona since 1992, AIDS, followed by drug overdose, has been the primary cause of death in the population under 35 years of age, ${ }^{33}$ and hence it is also the leading cause of YPLL. It must be noted that in Barcelona $53 \%$ of AIDS cases were intravenous drug users. ${ }^{34}$

A study on the evolution of AIDS mortality in France between 1983 and 1990 found a decrease in the relative contribution made by cases in the more favoured social categories to the detriment of working class and unemployed people. ${ }^{35}$ A nested case-control study of a cohort of homosexual men in Canada showed that a high socioeconomic level was associated with a slower progression of AIDS infection, independently of access to health services. ${ }^{36}{ }^{37}$

Both drug consumption and AIDS have been related to low socioeconomic level, ${ }^{38}{ }^{39}$ zones of poverty and zones with a population marginal to urban nuclei. ${ }^{40}{ }^{41}$ In Barcelona, the old inner city district of Ciutat Vella and the remaining wards with lower socioeconomic levels show the highest rates of drug users. ${ }^{42}{ }^{43}$ In addition, it has been shown that the prevalence of HIV-1 antibodies among injecting drug users attending a health care centre located in the inner city area was almost twice as large as the prevalence observed among drug users in health centres in the remaining areas. ${ }^{44}$

Wallace et al have theorised over the social and special diffusion of AIDS, and have explained how the disease spreads from epicentric nuclei of large cities to suburban areas. They have also stressed the great importance of social networks in the transmission of the disease, beyond individual behaviour. ${ }^{45} \mathrm{~A}$ study carried out in the Bronx (New York) described violent deaths (suicide and homicide) and mortality due to cirrhosis and to AIDS between 1970 and 1980, before and after

Table 4 Specific age mortality rates for the years 1983 and 1994 and slopes of regression lines in the two groups of wards in relation to cause of death and sex. Barcelona, 1983-94

\begin{tabular}{|c|c|c|c|c|c|c|c|}
\hline \multirow[b]{2}{*}{ Age groups (y) } & \multirow[b]{2}{*}{ Sex } & \multicolumn{3}{|c|}{ Wards of low socioeconomic level } & \multicolumn{3}{|l|}{ Rest of wards } \\
\hline & & 1983 rate (no) & 1994 rate (no) & $B$ & 1983 rate (no) & 1994 rate (no) & $B$ \\
\hline \multirow[t]{3}{*}{0} & $M$ & $1254.4(18)$ & $733.3(8)$ & $-61.76^{\star}$ & $571.1(40)$ & $554.2(29)$ & -26.67 \\
\hline & $\mathrm{F}$ & $818.4(11)$ & $1010.1(11)$ & -28.59 & $420.6(28)$ & $470.0(24)$ & -14.63 \\
\hline & $\mathrm{T}$ & $1043.5(29)$ & $871.6(19)$ & -45.58 & $497.8(68)$ & $512.6(53)$ & -20.80 \\
\hline \multirow{3}{*}{$1-14$} & $M$ & $29.1(8)$ & $14.5(3)$ & -1.38 & $20.5(25)$ & $13.8(13)$ & -0.85 \\
\hline & $\mathrm{F}$ & $30.7(8)$ & $25.7(5)$ & -0.85 & $17.4(20)$ & $17.9(16)$ & 0.28 \\
\hline & $\mathrm{T}$ & $29.9(16)$ & $20.0(8)$ & $-1.12^{\star}$ & $19.0(45)$ & $15.8(29)$ & -0.30 \\
\hline \multirow[t]{3}{*}{$15-24$} & $\mathrm{M}$ & $68.3(18)$ & $127.7(31)$ & 8.43 & $54.0(59)$ & $64.7(69)$ & 1.98 \\
\hline & $\mathrm{F}$ & $24.4(6)$ & $17.3(4)$ & 1.79 & $19.0(20)$ & $18.6(19)$ & 0.11 \\
\hline & $\mathrm{T}$ & $47.1(24)$ & 73.9 (35) & $5.17^{\star}$ & $36.8(79)$ & $42.2(88)$ & 1.08 \\
\hline \multirow[t]{3}{*}{$25-34$} & $\mathbf{M}$ & $175.4(35)$ & $512.2(109)$ & $35.68^{\star}$ & $83.2(78)$ & $201.7(198)$ & $14.80^{\star}$ \\
\hline & $\mathrm{F}$ & 49.1 (9) & $192.8(38)$ & $14.49^{\star}$ & $50.9(50)$ & $68.4(69)$ & $3.20^{\star}$ \\
\hline & $\mathrm{T}$ & $114.9(44)$ & $358.6(147)$ & $25.46^{\star}$ & $66.6(128)$ & $134.1(267)$ & $8.95^{\star}$ \\
\hline \multirow{3}{*}{$35-44$} & $\mathrm{M}$ & $236.0(42)$ & $424.7(71)$ & $23.43^{\star}$ & $155.2(136)$ & $264.0(226)$ & $10.79^{\star}$ \\
\hline & $\mathrm{F}$ & $153.4(27)$ & $227.6(37)$ & 3.56 & $83.0(79)$ & $99.4(94)$ & 0.96 \\
\hline & $\mathrm{T}$ & $194.9(69)$ & $327.6(108)$ & $13.71^{\star}$ & $117.6(215)$ & $177.6(320)$ & $5.59^{\star}$ \\
\hline \multirow[t]{3}{*}{$45-54$} & $\mathrm{M}$ & $804.9(160)$ & $819.0(139)$ & 1.77 & 482.1 (395) & $508.8(396)$ & 0.23 \\
\hline & $\mathrm{F}$ & $344.8(70)$ & $293.2(50)$ & -5.75 & 232.2 (209) & $217.5(186)$ & -2.48 \\
\hline & $\mathrm{T}$ & $572.4(230)$ & $555.5(189)$ & -1.78 & $351.3(604)$ & $356.3(582)$ & -1.19 \\
\hline \multirow[t]{3}{*}{$55-64$} & $\mathbf{M}$ & $1685.4(326)$ & $1418.7(270)$ & -10.95 & $1181.2(947)$ & $1051.9(842)$ & -5.65 \\
\hline & $\mathrm{F}$ & $693.7(152)$ & $558.5(117)$ & $-11.20^{\star}$ & $542.1(522)$ & $393.1(372)$ & -14.01 \\
\hline & $\mathrm{T}$ & $1158.7(478)$ & $968.0(387)$ & -10.27 & 832.4 (1469) & $695.0(1214)$ & $-9.87^{\star}$ \\
\hline \multirow[t]{3}{*}{$65-74$} & $\mathbf{M}$ & 3752.7 (394) & $3519.6(434)$ & -7.80 & 2965.7 (1439) & $2915.2(1630)$ & -16.32 \\
\hline & $\mathrm{F}$ & 2051.4 (323) & $1564.0(269)$ & $-38.43^{\star}$ & $1489.3(1081)$ & $1221.7(977)$ & $-25.17^{\star}$ \\
\hline & $\mathrm{T}$ & $2732.0(717)$ & $2380.6(793)$ & -21.85 & $2080.9(2520)$ & $1918.6(2607)$ & $-19.51^{\star}$ \\
\hline \multirow{3}{*}{$\geqslant 75$} & $M$ & $10855.6(576)$ & $9988.1(586)$ & -50.49 & $9297.8(2700)$ & 9363.9 (3143) & 1.66 \\
\hline & $\mathrm{F}$ & $7274.2(827)$ & 7159.9 (899) & -15.85 & $6875.2(4072)$ & $7110.4(4841)$ & 26.98 \\
\hline & $\mathrm{T}$ & $8413.8(1403)$ & $8060.6(1485)$ & -26.79 & $7672.3(6772)$ & $7854.6(7984)$ & 19.00 \\
\hline
\end{tabular}

M: males, F: females, T: males and females, B: slope of regression line, rate: age specific mortality rate per 100000 inhabitants, $n$ : number of deaths ${ }^{\star} \mathrm{p}<0.05$. 

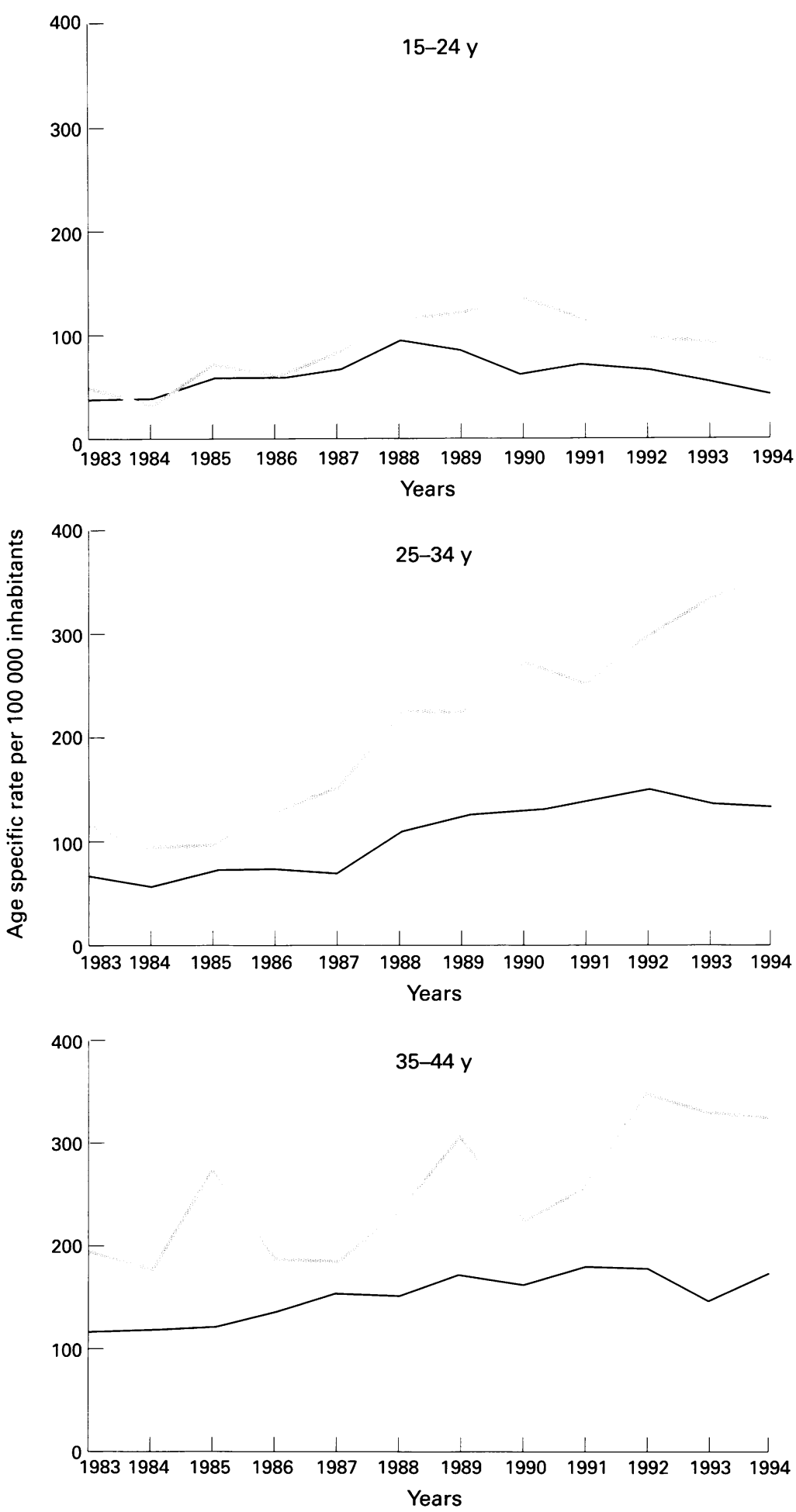

Figure 3 Evolution of mortality in the age groups, 15-24, 25-34, and 35-44 years in the low socioeconomic level wards (grey, upper lines) and other wards (lower lines). Both sexes, Barcelona, 1983-94. women, however, rates increased for manual occupations and decreased for non-manual ones. ${ }^{6}$ In contrast, Kunst et al found that lung cancer mortality was higher in wealthier areas, but that the differences lessened over the years, and in the last year of the study (1980) they were practically non-existent. ${ }^{10}$ It should be noted that in Barcelona, it is only since the 1980 s that men in lower social classes have smoked more than those in higher classes, a situation which has been reversed in women, in whom the higher social classes still smoke more. ${ }^{23}$ This behaviour is different from that found in most of the developed countries, ${ }^{47}$ including northern European countries. ${ }^{48}$

With regard to mortality from cerebrovascular diseases, the reduction in inequalities observed in Barcelona is different from the results of other studies. For example, in their study of mortality trends in the USA between 1961 and 1979, Feldman et al found that the increase in inequalities among men was due to cardiovascular causes. ${ }^{30}$ Marmot $^{6}$ and Kunst ${ }^{10}$ have also described an increase in inequalities due to cardiovascular diseases. There were no important changes in coronary mortality in either group of wards in Barcelona during the 12 year study period despite of a wealth of published material on inequalities in coronary disease mortality indicating that the reduction has been more marked in higher socioeconomic groups than in lower ones. ${ }^{49-51}$

Infant mortality is one of the indicators which tends to decline when social conditions of the population improve..$^{52}$ Classically, it has been found to be higher among lower socioeconomic groups. ${ }^{53}$ The downward trend in infant mortality and mortality in the 1-14 year age group in wards with lower socioeconomic level in Barcelona could be partly related to the implementation since 1986 of a programme to reduce this mortality in the district of Ciutat Vella. ${ }^{55}$

As mentioned earlier, in Barcelona the increase in specific rates of mortality among the groups aged 15 to 44 has been greater in the low socioeconomic level wards than in the remaining one, and this can be explained by the influence of drug use and AIDS in this age group. Studies of mortality trends in geographical areas of the United Kingdom have found an increase in inequalities among younger ages, but they have not described the influence of AIDS or drug overdose as major contributors to such an increase. ${ }^{856}$

When interpreting the Barcelona data, the differential decline in population among wards needs to be taken into account. Thus, between 1986 and 1991 it fell by $6.4 \%$ in the low socioeconomic wards compared with a reduction of $2.8 \%$ in the other wards. It is possible that a less favoured population was concentrated in the former groups of wards, whether because those with better health migrated or those who moved in had worse health, and that this favoured the existence of a selection bias. Although no individual data are available to check this hypothesis, comparison of the distribution of social classes in the two groupings of wards for the years 1983 and 1992 did not 
show any changes. ${ }^{23}$ Despite this possible limitation, it should be noted that the differential increase in mortality in the two groups of wards for certain causes of death, beginning in 1986 (particularly AIDS and drug overdose) and in certain age groups, was too great to be attributable to selection processes. Moreover, from a public health standpoint, the results indicate which geographical areas should be especially targeted in the setting of priorities for health interventions.

\section{IMPLICATIONS FOR INTERVENTION}

The implications of this study for public health are that more equitable health policies must be implemented. Based on the Whitehead recommendations, political initiatives may be focused on four levels of action as follows ${ }^{57}$ :

- Firstly, policies based on the premise that increasing knowledge, motivation, competence, or abilities at individual level facilitate changes in risk related behaviours (for example tobacco consumption, physical exercise, sexual practices, drug consumption, etc).

- Secondly, policies addressed to the community, in the sense of increasing social networks and of reinforcing the whole community against risks to health, are needed.

- Thirdly, there must be improved access to essential facilities and services, which implies policies to improve the conditions under which people live and work.

- Finally, macroeconomic and cultural change are needed to reduce poverty and inequalities in society.

All four levels are important for the reduction of social inequalities in health. The first two levels fall more within the scope of public health, the third also requires participation from other areas, and the fourth refers fully to multi sectorial policies.

Funding: this study has been supported by the Municipal Institute of Health of Barcelona and partly by a grant from de Fondo de Investigaciones Sanitarias (FIS 96/0825)

Conflicts of interest: none.

1 Marmot MG, Kogevinas M, Elston MA. Social/economic status and disease. Ann Rev Public Health 1987;8: 111 -35.

2 Syme SL, Berkman LF. Social class, susceptibility ens sickness. Am $\mathcal{F}$ Epidemiol 1976; 104:1-8.

3 Black D, Morris JN, Smith C, Townsend P. The Black report. In: Townsend P, Davidson N, Whitehead M, eds. Inequalities in health: the Black report and the health divide. London: Penguin Books, 1988.

4 Whitehead M. The health divide. In: Townsend P, Davidson, Whitehead $\mathrm{M}$, eds. Inequalities in health: the Black report and the health divide. London: Penguin Books, 1988.

5 Davey Smith G. Morris J. Increasing inequalities in the health of the nation. BMF 1994;309: 1453-4.

6 Marmot MG, McDowall ME. Mortality decline and widening social inequalities. Lancet 1986;ii:274-6.

7 Pamuk ER. Social class inequality in mortality from 1921 to 1972 in England and Wales. Pop Stud 1985;39: 17-31.

1972 in England and Wales. Pop Stud 1985;39: 17-31.
8 Phillimore P, Beattie A, Townsend P. Widening inequality in Phillimore P, Beattie A, Townsend P. Widening inequalit
northern England, 1981 -91. BMF 1994;308: 1125-8.

9 Pappas G, Queen S, Hadden W, Fisher G. The increasing disparity in mortality between socioeconomic groups in the United States, 1960 and 1986. N Engl F Med 1993;329: 1039

10 Kunst AK, Looman WN, Mackenbach JP. Socio-economic differences in the Netherlands in 1950-1984: A regional study of cause-specific mortality. Soc Sci Med 1990;31:14152.

11 Pascual Esteve JM. La politica social en España. In: Borja J, Castells M, Dorado R. Quintana I, ed. Las grandes ciudades en la decada de los noventa. Madrid: Editorial Sistema, 1990;594-64

12 Flynn P. Medicion de la salud en las ciudades. In: Ashton J. ed. Ciudades sanas. Barcelona: Masson SA, 1993;31-42.

13 Hume D, Womersley J. Analysis of death rates in the population aged 60 years and over of Grater Glasgow by postcode sector of residence. $\mathcal{F}$ Epidemiol Community Health 1985;39:357-63.

14 McCord C, Freeman HP. Excess mortality in Harlem. $N$ Eng f Med 1990;322: 173-7.

15 Townsend P, Simson D, Tibbs N. Inequalities in health in the city of Bristol: a preliminary review of statistical evidence. Int $\mathcal{f}$ Health Services 1985;15:637-45.

16 Ramis-Juan O, Sokou K. Social health inequalities in South European countries: is it a different problem? In: Fox J. ed. Health Inequalities in European countries. Aldershot: European Science Foundation, Gower, 1989;301-16.

17 Regidor E, Gutiérrez-Fisac JL, Rodríguez C. Increased socioeconomic differences in mortality in eight spanish socioeconomic differences in mortality

18 Borrell $\mathrm{C}$, Plasència $\mathrm{A}$, Pañella $\mathrm{H}$. Excés de mortalitat en un àrea urbana cèntrica: el cas de Ciutat Vella a Barcelona. Gac Sanit 1991 ;5:243-53.

19 Costa J. Desigualtats en la mortalitatals barris de Barcelona: la seva relació amb l'atur, I'analfabetisme ila categoria professional. Barcelona: Universitat Autònoma de Barcelona, 1989. MD Thesis.

20 Arias A, Rebagliato M, Palumbo MA, et al. Desigualdades en salud en Barcelona y Valencia. Med Clin (Barc) 1993;100:281-7.

21 Borrell C, Arias A. Desigualtats en mortalitat als barris de Barcelona. Gac Sanit 1993;7:205-20.

22 Borrell C, Arias A. Socio-economic factors and mortality in urban settings: the case of Barcelona (Spain). $\mathcal{f}$ Epidemio Comm Health 1995;49:460-5.

23 Borrell C. Evolució de les desigualtats socials en salut a la ciuta de Barcelona, 1983-1992. Barcelona: Universitat Autònoma de Barcelona, 1995, MD Thesis.

24 Shyrock HS, Siegel JS. The methods and materials of demography. New York: Academic Press, Inc 1976

25 Clasificacion Internacional de Enfermedades, $9^{a}$ revisión. Washington: OPS/OMS, 1995.

26 Rates and rates standardisation. In: Breslow NE, Da $\mathrm{NE}$,eds. Statistical methods in cancer research. Vol Il: The design and analysis of cohort studies. Lyon: International Agency For Research on Cancer, 1987;48-81.

27 Romeder JM, McWhinnie JR. Potential years of life lost between ages 1 and 70: an indicator of premature mortality for health planning. Int $\mathcal{F}$ Epidemiol 1977;6: 143-51.

28 Kleinbaum DG, Kupper LL, Muller KE. Applied regression analysis and other multivariable methods. 2nd ed. Boston: PWS-KENT Publishing Company, 1987.

29 McCarron PG, Davey Smith G, Womersley JJ. Deprivation and mortality in Glasgow: changes from 1980 to 1992 BMF 1994;309:1481-2.

30 Feldman JJ, Makuc DM, Kleinman JC, Cornoni-Huntley J National trends in educational differentials in mortality. Am f Epidemiol 1989;129:919-33.

31 Castilla J, Iñigo J, Sendra JM, Tello $\mathrm{O}$. Años potenciales de vida perdidos por sindrome de inmunodeficiencia adquirida en España, 1981-1990. Med Clin (Barc) 1993;100 245-8.

32 Casabona J, Blanch C, Vall M, Salvador X. Premature mortality related to AlDS among men and women in Catalonia AIDS 1993;7: 1099-103.

33 Montellà N, Borrell C, Brugal MT, Plasència A. Evolución de la mortalidad en los jóvenes de la ciudad de Barcelona. Med Clin (Barc) 1997; 108:241-7.

34 Caylà JM, Jansà JM, Iglesias B, Plasència $\mathrm{A}$. Epidemiologia del síndrome de inmunodeficiencia adquirida en Barcelon ( 1981 - 1991). Estudio descriptivo y de tendencies temporales. Med Clin (Barc) 1993;101:286-93.

35 Jougla E, Hatton F, Le Toullec A, Michel E. Caractéristiques de l'évolution de la mortalité par SIDA en France de 1983 à 1990. Rev Epidém Santé Pub 1992;40:164-74.

36 Schechter MT, Hogg RT, Aylward B, Craib KJP, Le TN, Montaner JSG. Higher socioeconomic status is associated with slower progression of HIV infection independent of access to health care. $\mathcal{F}$ Clin Epidemiol 1994;47:59-67.

37 Hogg R. Strathdee SA, Craib KJP, O'Shaughnessy MV Montaner JSG, Schechter MT. Lower socioeconomic status and shorter survival following HIV infection. Lance 1994;344: 1120-4.

38 Zunzunegui V, Rodriguez MA, Sarasqueta C. Drogadicción intravenosa y riesgo de infección por VIH en Madrid, 1990. Gac Sanit 1993;34:2-1

39 Simon PA, Hu DJ, Diaz T. Kerndt PR. Income and AIDS rates in Los Angeles County. AIDS 1995;9:281-4

40 Wilkinson J, Lawes G, Unell I, Bradbury J, Maclean P. Problematic drug use and social deprivation. Public Health 1987; 101:165-8.

41 Urtiaga M, Extramiana E, Moreno C, Ardanaz E, Martínez M. Aproximación a la prevalencia de usuarios de heroína en Navarra en 1990. Gac Sanit 1993;7:56-62.

42 Domingo-Salvany A, Hartnoll RL, Antó JM. Opiate and cocaine consumers attending Barcelona emergency rooms: a one year survey (1989). Addiction 1993;88:1247-56.

43 Torralba L, Brugal MT, Villalbí JR, Tortosa MT, Toribio A Valverde JL. Mortality due to acute adverse drug reactions: opiates and cocaine in Barcelona, 1989-93. Addiction 1996; 91:419-26.

44 Roca J, Vlahov D, Borrell C, Jansà JM, Brugal MT, Yazbeck $\mathrm{H}$, Muñoz A. Geographic variation in HIV infection among injecting drug users within Barcelona. Int $\mathcal{F}$ Addiction 1995 30:219-29.

45 Wallace R, Fullilove M, Fullilove R, Gould P, Wallace D Will AIDS be contained within U.S. minority populations? Soc Sci Med 1994;39:1051-62. 
46 Wallace $R$. Urban desertification, public health and public order: "shrinkage", violent death, substance abuse and order: "shrinkage", violent death, substance ab

47 Pierce JP. International comparisons of trends in cigarette smoking prevalence. Am f Public Health 1989;79:152-7.

48 Graham H. Smoking prevalence among women in the European community, 1950-1990. Soc Sci Med 1996;43: 243-54.

49 Wing S. Social inequalities in the decline of coronary mortality. Editoria. Am 7 Public Health 1988;78:1415-6.

50 Kaplan GA, Keil JE. Socioeconomic factors and cardiovascular disease: a review of the literature. Circulation 1993;88: 1973-98.

51 Wing S, Casper M, Davis W, Hayes C, Riggan W. Tyroler HA. Trends in the geographic inequality of cardiovascular HA. Trends in the geographic inequality of cardiovascular
disease mortality in the United States, 1962-1982. Soc Sci Med 1990;30:261-6.
52 Wise PH. Poverty, technology and recent trends in the United States infant mortality rate. Paediatr Perinat Epidemiol 1990;4:390-401.

53 Leon AD, Vagero D, Olausson PO. Social class differences in infant mortality in Sweden: comparison with England and Wales. BMF 1992;305:687-91.

54 Hogue CJR, Hargraves MA. Class, race and infant mortality in the United States. Am F Public Health 1993;83:9-12.

55 Díez E, Villalbi JR, Benaque A, Nebot M. Desigualdades de salud maternoinfantil: impacto de una intervention. $G a c$ Sanit 1995;9:224-31.

56 McLoone P, Boddy FA. Deprivation and mortality in Scotland, 1981 and 1991. BMF 1994:309:1465-70.

57 Whitehead M. Tackling inequalities: a review of policy initiatives. In: Benzeval $M$, Judge J, Whitehead policy Tackling inequalities in health. An agenda for action. London: King's Fund, 1995;22-52. 